University of Nebraska - Lincoln

DigitalCommons@University of Nebraska - Lincoln

Faculty Publications from the Harold W. Manter Laboratory of Parasitology

$10-1975$

\title{
A Review of the Genus Allassostomoides Stunkard 1924 (Trematoda: Paramphistomidae) with a Redescription of $A$. chelydrae (Maccallum 1919) Yamaguti 1958
}

Daniel R. Brooks

University of Toronto,dnlbrooks@gmail.com

Follow this and additional works at: https://digitalcommons.unl.edu/parasitologyfacpubs

Part of the Parasitology Commons

Brooks, Daniel R., "A Review of the Genus Allassostomoides Stunkard 1924 (Trematoda:

Paramphistomidae) with a Redescription of A. chelydrae (Maccallum 1919) Yamaguti 1958" (1975).

Faculty Publications from the Harold W. Manter Laboratory of Parasitology. 209.

https://digitalcommons.unl.edu/parasitologyfacpubs/209

This Article is brought to you for free and open access by the Parasitology, Harold W. Manter Laboratory of at DigitalCommons@University of Nebraska - Lincoln. It has been accepted for inclusion in Faculty Publications from the Harold W. Manter Laboratory of Parasitology by an authorized administrator of DigitalCommons@University of Nebraska - Lincoln. 


\title{
A REVIEW OF THE GENUS ALLASSOSTOMOIDES STUNKARD 1924 (TREMATODA: PARAMPHISTOMIDAE) WITH A REDESCRIPTION OF A. CHELYDRAE (MACCALLUM 1919) YAMAGUTI 1958
}

\author{
Daniel R. Brooks* \\ School of Life Sciences, University of Nebraska-Lincoln, and Harold W. Manter Laboratory, \\ University of Nebraska State Museum, Lincoln, Nebraska 68508
}

ABSTRACT: A redescription of Allassostomoides chelydrae and a review of the genus is presented, based on new collections of A. chelydrae and A. parvus from Nebraska, and examination of all type material relating to the genus. A. chelydrae, A. parvus, and A. louisianaensis are considered valid species. New host records for A. chelydrae are Bufo Americanus, Rana catesbeiana, Chrysemys picta, and Graptemys pseudogeographica.

From March 1973 to October 1974, 40 specimens of digeneans belonging to the genus Allassostomoides Stunkard 1924 were collected from Rana catesbeiana, Chelydra serpentina, Chrysemys picta, and Graptemys pseudogeographica in Nebraska. The study of these specimens included a reexamination of all type material relating to the genus.

Worms were removed from the host rectum, flattened with slight coverslip pressure, fixed with AFA, stored temporarily in $70 \%$ ethanol, stained with Mayer's hematoxylin, and mounted in Canada balsam for study as whole mounts. Representative specimens are on deposit with the Harold W. Manter Laboratory. All measurements are in microns unless otherwise stated.

\section{Allassostomoides chelydrae (MacCallum 1919) Yamaguti 1958 \\ synonym: Paramphistomum chelydrae MacCallum 1919}

(Figs. 1, 2)

Stunkard (1924) noted discrepancies between MacCallum's (1919) written description and figure. The following redescription is based on the three specimens used by MacCallum, seven specimens from Dr. Horace W. Stunkard's collection, and 10 specimens collected in Nebraska. MacCallum's original measurements are included in parentheses.

\section{Redescription}

Body elongate, robust, with prominent lateral projections at posterior end; eyespot pigment dif-

Received for publication 3 April 1975.

* Present address: Gulf Coast Research Laboratory, P.O. Box A.G., Ocean Springs, Mississippi. fuse; length 2.114 to $5.589 \mathrm{~mm}$ ( $5.5 \mathrm{~mm}$ ), width 0.494 to $1.758 \mathrm{~mm}(1.6 \mathrm{~mm})$. Oral sucker terminal, 300 to 802 (90) long by 227 to 632 (60) wide; 2 small diverticula present at posterior end of oral sucker. Esophagus muscular, passing between diverticula, surrounded by gland cells, with posterior bulb 125 to 324 ( 80 ) long. Cecal bifurcation $1 / 4$ body length from anterior end; ceca ending near posterior end of body. Acetabulum terminal with elongate ventral aperture, 462 to 1,240 (130) by 421 to 1,200 ( 130 ); ratio of sucker widths $1: 1.85$ to $1: 1.9$. Testes lobed, occasionally highly irregular, tandem or oblique, in anterior region of intercecal space; anterior testis 121 to 389 (43) by 121 to 308 (25), posterior testis 121 to 405 (60) by 121 to 365 ( 40 ). Vasa efferentia join vas deferens anterodorsal to anterior testis; vas deferens joins convoluted external seminal vesicle dorsal to cirrus sac; cirrus sac immediately postbifurcal, saccate, containing convoluted cirrus, 104 to 455 (not given) long. Genital pore ventral, median, immediately postbifurcal. Ovary spherical, 65 to 275 (30) in diameter, posttesticular, at midbody. Ootype posterodorsal to ovary; Laurer's canal and prominent Mehlis' gland present. Uterus extending anteriorly in intercecal region, somewhat coiled between ovary and posterior testis, passing between testes, joining shallow genital atrium dorsolateral to cirrus sac. Vitelline follicles numerous, irregular, extending from cecal tips to testicular level intercecally and to level of cirrus sac extracecally, with some follicles dorsal and ventral to ceca; vitelline reservoir posterodorsal to ootype. Mature uterine eggs 154 to 184 (20) by 105 to 123 (12). Lymph system composed of 3 tubes on each side of body, 1 lateral and 2 mesad to ceca; mesad pair arranged dorsoventral to each other; lymph reservoir at posterior end of body, dorsal to excretory vesicle. Excretory vesicle saccate, short; main collecting ducts paired, each spiraling around a cecum; excretory pore dorsal, immediately preacetabular.

Hosts and localities of material studied:

Chelydra serpentina (L.), common snapping turtle (type host) 

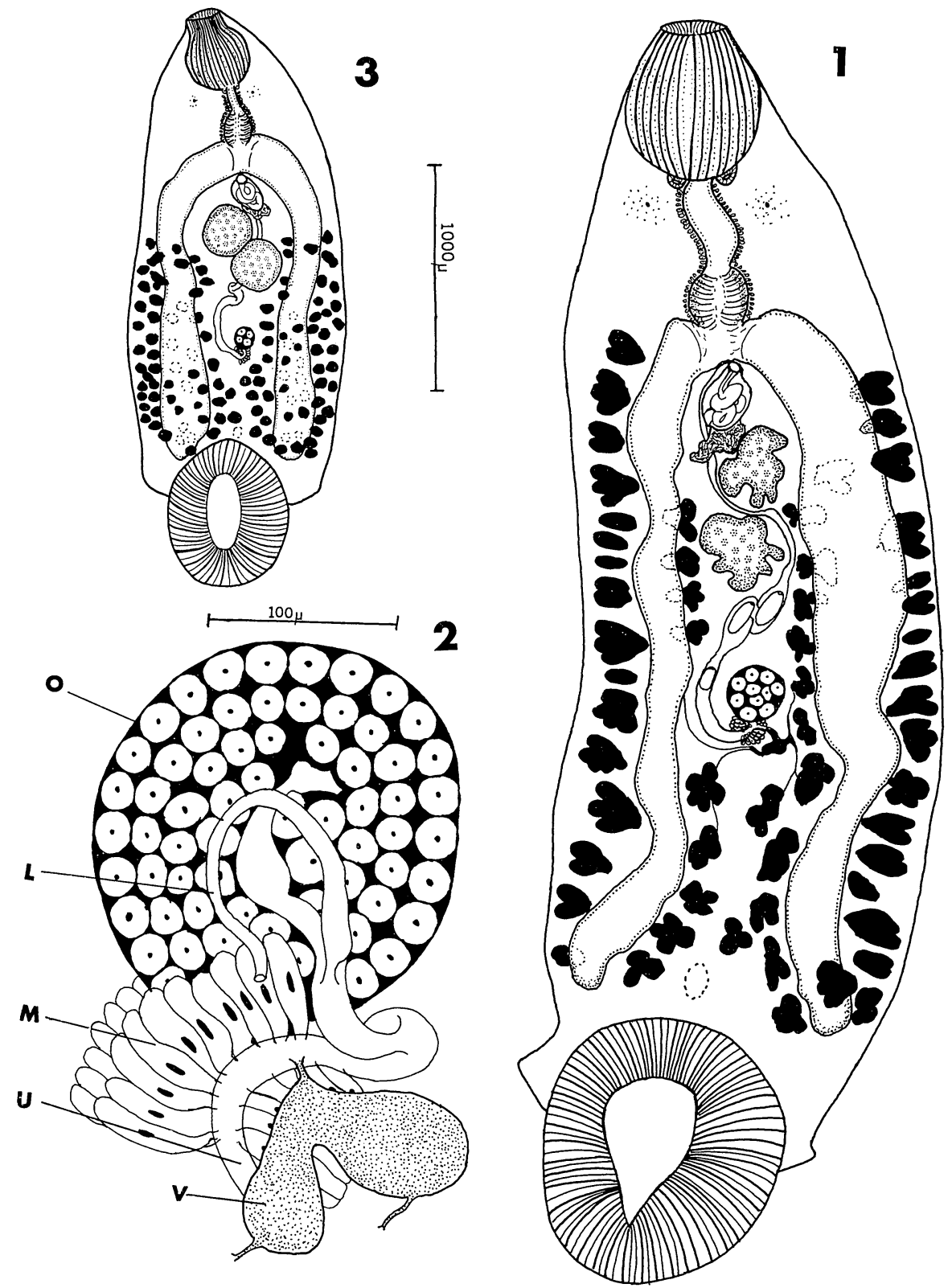

Figures 1-3. Allassostomoides chelydrae (MacCallum 1919) Yamaguti 1958 and A. parvus (Stunkard 1916) Stunkard 1924. 1. Allassostomoides chelydrae, ventral view of lectotype. 2. A. chelydrae, dorsal view of ootype from a homotype. 3. A. parvus, ventral view of a specimen from Rana catesbeiana in Nebraska. Figs. 1 and 3 drawn to same scale. Abbreviations: O, ovary; M, Mehlis' gland; U, uterus; V, vitelline reservoir; L, Laurer's canal.

New York Aquarium, locality unknown (MacCallum, 1919)

Louisiana (AMNH Nos. 796 to 802; Stunkard, unpublished)

10 miles south of Humboldt, Nebraska (present report)
Chrysemys picta (Schneider), painted turtle (new host record)

1.5 miles south of Brownville, Nebraska (present report)

Graptemys pseudogeographica (Grey), false map turtle (new host record) 
1.5 miles south of Brownville, Nebraska (present report)

Bufo americanus (Holbrook), American toad (new host record)

Oklahoma (AMNH Nos. 803 to 804; gift of Dr. Louis Bouchard, Stunkard, pers. comm.; Stunkard, unpublished)

Rana catesbeiana Shaw, bullfrog (new host record)

0.5 miles west of Verdon, Nebraska (present report)

Type specimens: The 3 specimens used by MacCallum (1919) are arranged side-by-side on a single slide (USNM Helm. Coll. No. 36261). The middle specimen is clearly identifiable as the one figured by MacCallum, and I am designating it the lectotype by circling it; the other 2 specimens are paralectotypes. The 10 specimens collected in Nebraska are designated homotypes.

Lectotype and 2 paralectotypes USNM Helm. Coll. No. 36261

2 homotypes USNM Helm. Coll. Nos. 73946-7

2 homotypes H. W. Manter Laboratory, University of Nebraska State Museum No. 20074

Other homotypes in collection of author

\section{Allassostomoides parvus (Stunkard 1916) Stunkard 1924 \\ synonyms: Allassostoma parvum Stunkard 1916 Allassostoma Allassostomoides parvum Stunkard 1924 \\ (Fig. 3)}

The holotype and 3 specimens used by Stunkard (1924) in the redescription of this species were studied in addition to 40 specimens collected in Nebraska. All specimens agree with the redescription of the species, except that mature eggs range from 164 to 176 $\mu$ long rather than averaging $145 \mu$ long.

Hosts and localities of material studied:

Chelydra serpentina (type)

Urbana, Illinois (AMNH No. 792; Stunkard, $1916,1917)$

Pseudemys floridana (LeConte) (= Chrysemys $\mathrm{f}$.), Florida painted turtle

Florida (AMNH Nos. 793 to 795; Stunkard, 1924)

Chrysemys picta

10 miles south of Humboldt, Nebraska (present report)

Rana catesbeiana

10 miles south of Humboldt, Nebraska (present report)

Type specimens: Holotype AMNH No. 792.

\section{Allassostomoides louisianaensis Christian and White 1973}

This is the only other reported species of the genus. The holotype was examined and found to agree completely with the description by Christian and White (1973). It has been reported only from the pig frog, Rana grylio, in Louisiana.

Hosts and localities of material studied:

Rana grylio (Stejneger), pig frog (type)

Louisiana (Christian and White, 1973)

Type specimens: Holotype USNM Helm. Coll. No. 72297; 2 paratypes USNM Helm. Coll. No. 72298 .

\section{Remarks}

Allassostomoides chelydrae has lobed to highly irregular noncontiguous testes and extracecal vitelline follicles extending to the level of the cirrus sac or genital pore. A. parvus has spherical contiguous testes and extracecal vitelline follicles extending only to the middle of the anterior testis. Allassostomoides louisianaensis possesses a seminal vesicle and cirrus sac which are much larger in proportion to the body than either of the other two species, but resembles A. chelydrae in the distribution of the vitelline follicles and A. parvus in having contiguous testes.

\section{DISCUSSION}

Stunkard $(1916,1917)$ erected the genus Allassostoma for A. magnum (type) and A. parvum from turtles in Illinois. MacCallum (1919) described Paramphistomum chelydrae from Chelydra serpentina of unknown locality from the New York Aquarium. Stunkard (1924) redescribed A. parvum based on new collections from turtles in New York and Florida and erected the subgenus Allassostomoides for it. At the same time, he suggested that $P$. chelydrae might be a synonym of $A$. parvum based on irregularities in MacCallum's (1919) description. Stunkard (1925) and Fuhrmann (1928) published synopses of the amphistomes and digeneans, respectively, each listing Allassostomoides as a distinct genus with no discussion. Beaver (1929) and Krull (1933) published on the life cycle of $A$. parvum, but their reports are sufficiently divergent to suggest that different species may have been involved. Travassos (1934) elevated Allassostomoides to generic rank, and designated $A$. parvum the type species, listing $P$. chelydrae as a synonym of $A$. parvum, as did Skrjabin (1947). Yamaguti $(1958,1971)$ accepted $P$. chelydrae as a valid species, but transferred it 
to Allassostomoides. At the same time, he emended the name of the type species to $A$. parvus to agree in gender with the generic name. Other reports of A. parvus and A. chelydrae have contained no morphological data. Because it has generally been considered to be a synonym of $A$. parvus since 1924 , specimens of $A$. chelydrae collected in subsequent studies may have been reported as $A$. parvus. The specimens collected in Nebraska fall into two distinct categories, one of which agrees with $A$. chelydrae and the other with $A$. parvus.

\section{ACKNOWLEDGMENTS}

The author expresses appreciation to Dr. John D. Lynch, School of Life Sciences, University of Nebraska-Lincoln, for his aid in identifying hosts; to Dr. Horace W. Stunkard and Dr. E. Kirsteuer for arranging the loan of specimens from the American Museum of Natural History; to Dr. J. Ralph Lichtenfels for the loan of type material from the USNM Helminthological Collection; and to Mrs. Mary H. Pritchard, curator of the Harold W. Manter Laboratory, University of Nebraska State Museum, under whose direction this study was undertaken.

\section{LITERATURE CITED}

BeAver, P. C. 1929. Studies on the development of Allassostoma parvum Stunkard. J Parasitol 16: 13-23.
Christian, F. A., and L. L. White. 1973. The genus Allassostomoides Stunkard, 1924 with description of Allassostomoides louisianaensis n. sp. (Trematoda: Paramphistomidae), from the pig frog, Rana grylio in Louisiana. Am Midl Nat 90: 218-220.

FunrmanN, O. 1928. Zweite Klasse des Cladus Plathelminthes: Trematoda. Handb Zool 2: 1-140.

KRULL, W. H. 1933. Notes on Allassostoma parvum Stunkard. J Parasitol 20: 109.

MacCallum, G. A. 1919. Notes on the genus Telorchis and other trematodes. Zoopathologica 1: 88-89.

SkrJabin, K. I. 1947. Trematodes of Animals and Man. Vol. 3: 623 p.

StunKard, H. W. 1916 . On the anatomy and relationships of some North American trematodes. J Parasitol 3 : 21-27.

- 1917. Studies on North American Polystomidae, Aspidogastridae, and Paramphistomidae. Ill Biol Monogr 3 : 64-71.

- 1924. On some trematodes from Florida turtles. Trans Am Microsc Soc 43: 97-117.

- 1925. The present status of the amphistome problem. Parasitology 17: 137-148.

Travassos, L. P. 1934. Synopse dos Paramphistomoidea. Mem Inst Oswaldo Cruz 29: 19-178.

YamaGUTI, S. 1958. Systema Helminthum. Vol. 1. The Digenetic Trematodes of Vertebrates. Part 1. Interscience Publ., New York, 979 p.

- 1971. Synopsis of the Digenetic Trematodes of Vertebrates. Keigaku Publ. Co., Tokyo, $1772 \mathrm{p}$. 